\title{
Clinical Reasoning: A 58-year-old woman presents with progressive memory deficits, odd behavior, and falls
}

Tara C. Carlisle, MD, PhD, Kristin M. Galetta, MD, Scott M. McGinnis, MD, and Tamara Bockow Kaplan, MD Neurology ${ }^{\circledR}$ 2020;94:e557-e561. doi:10.1212/WNL.0000000000008896
Correspondence

Dr. Carlisle

tcarlisle@partners.org

\section{Section 1}

A 58-year-old woman presented to the emergency department with progressive memory deficits, odd behavior, and recurrent falls.

The patient's family noted slow decline over several years, then marked decompensation the week prior to presentation. Over several years, the patient became less talkative and expressed less emotion, then developed rigid ritualistic behaviors (i.e., obsessive dog walking, repetitious bathroom use). A few months previously, concerns arose regarding her performance as an assistant teacher. Days before presentation, she did not answer when family attempted contact, she greeted a guest in the nude, and she had episodes of incontinence followed by progressive unsteadiness with multiple falls.

On admission, the patient was orientated, displayed 2 out of 3 delayed recall ( 5 minutes), named 11 words starting with F (1 minute), and comprehended complex sentences. She had paucity of speech and aprosody. She correctly pantomimed common tasks. Cranial nerves were intact. She displayed masked facies and mild asymmetric increased tone with cogwheeling and bradykinesia (both left greater than right). She had a fine postural/kinetic tremor. She had patchy hyperreflexia including brisk patellar reflexes (right greater than left). She had positive jaw jerk, glabellar reflex, and rooting reflex. Babinski response was absent. She had a wide-based gait and difficulty walking tandem.

\section{Question for consideration:}

1. Based on the history and examination, where can the patient's presentation be localized?

GO TO SECTION 2 


\section{Section 2}

The patient displays features consistent with frontal or temporal lobe dysfunction, including changes in personality and behavior (i.e., disinhibition, emotional blunting, and obsessive-compulsive behaviors), reduced speech initiation, and relatively poor verbal fluency. She displays extrapyramidal signs with masked facies, cogwheeling, bradykinesia, and postural instability. Her diffuse hyperreflexia with jaw jerk could suggest an upper motor neuron lesion above the foramen magnum or a systemic etiology. Primitive reflexes (e.g., rooting and glabellar reflexes) are nonspecific, but potentially suggest diffuse cerebral dysfunction, frontalassociated dysfunction, or extrapyramidal dysfunction (e.g., glabellar reflex).
The patient was previously healthy other than recent hypertension and depression diagnoses. She drank heavily for nearly 30 years but recently cut back. She lives in a Lyme endemic area. Family history was notable for late-onset (50s) schizophrenia and severe depression in her grandmother and mother, respectively.

Basic admission laboratory studies identified hyponatremia (116 mEq/L) and hyperthyroidism (thyroid-stimulating hormone $0.03 \mathrm{mIU} / \mathrm{L}$ and free T4 $1.9 \mathrm{ng} / \mathrm{dL}$ ). MRI brain without contrast showed white matter disease out of proportion for age and mild atrophy.

\section{Questions for consideration:}

1. Can the toxic-metabolic abnormalities alone explain the patient's presentation?

2. Does the family history narrow the diagnosis?

GO TO SECTION 3 


\section{Section 3}

The hyponatremia was consistent with syndrome of inappropriate antidiuretic hormone secretion (SIADH). The patient's serum sodium was $136 \mathrm{mEq} / \mathrm{L} 1$ month previously. Hyponatremia may have contributed to her worsening gait and confusion, but would not explain the changes in behavior or constellation of extrapyramidal signs. Her mild hyperthyroidism could have contributed diffuse tremor and hyperreflexia.

The patient's family history of late-onset psychiatric disease is notable. Familial frontotemporal dementia (FTD), such as autosomal dominant forms associated with repeated expansions in the C9orf 72 gene, can present with psychosis and features of dementia including apathy that can be mistaken for depression. More workup would be required to diagnose FTD; the differential remained broad given her additional acute and subacute features.

A week after the patient's admission, she developed a peripheral right facial palsy prompting additional workup. Her
CSF was notable for lymphocytic pleocytosis (110 white blood cells $/ \mathrm{mm}^{3}$; 50\% lymphocytes, $25 \%$ neutrophils), no red blood cells, normal CSF glucose $(57 \mathrm{mg} / \mathrm{dL})$, and elevated CSF total protein $(303.6 \mathrm{mg} / \mathrm{dL})$. She was started on empiric meningitis coverage.

MRI brain with gadolinium showed bilateral leptomeningeal enhancement involving multiple cranial nerves (III, V, and VII/VIII bundle), and MRI spine displayed abnormal enhancement along multiple nerve roots of the cervical and thoracic spine and thickening with enhancement of the cauda equina (figure). A CT-PET scan showed multiple FDG-avid lymph nodes concerning for granulomatous disease. Transthoracic echocardiogram revealed hypertrophic cardiomyopathy.

\section{Question for consideration:}

1. What unifying diagnosis would incorporate cognitive deficits, leptomeningeal disease, granulomas, and cardiomyopathy?

Figure Initial MRI brain without contrast and follow-up MRI brain and MRI lumbar spine with contrast
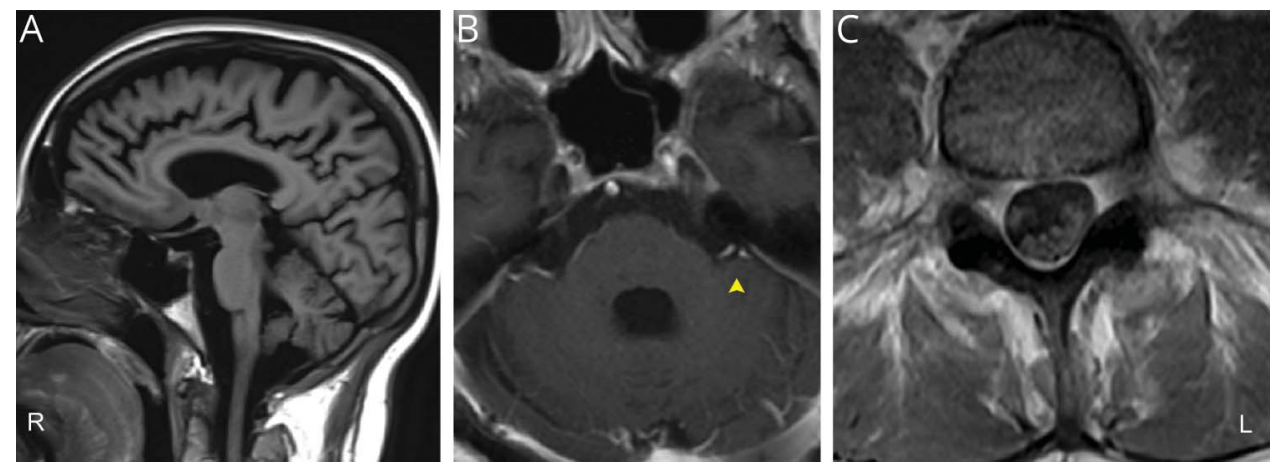

(A) Initial presenting T2 sagittal MRI brain without contrast displays atrophy. Follow-up contrast images show (B) left cranial nerve VII and VIII enhancement (arrowhead) and (C) cauda equina enhancement. 


\section{Section 4}

The differential was expanded to include neurosarcoidosis, incorporating cognitive deficits, granulomas, cardiomyopathy, and leptomeningeal disease. However, since the patient's chronic symptoms could possibly be from a separate process, neuroborreliosis, varicella-zoster virus (VZV) encephalitis, and herpes simplex virus (HSV) type 2 (Mollaret meningitis) were considered as etiologies for her acute symptoms.

Serum studies were notable for positive Lyme immunoglobulin G ( $\operatorname{IgG}) /$ immunoglobulin M (IgM) with confirmatory Western blot, but negative T-SPOT, HIV, Venereal Disease Research Laboratory (VDRL) test, and serum protein electrophoresis. Serum and CSF paraneoplastic panels and CSF NMDA receptor antibody were unremarkable. Initial CSF studies were notable for VZV IgM 2.08 ISR (positive), HSV 1/2 IgG 9.46 IV (positive), and HSV IgM 0.94 IV (equivocal) but negative HSV 1/2 PCR; negative or normal CSF studies included Biofire, Borrelia PCR, VDRL, West Nile virus (WNV) IgG, WNV IgM, flow cytometry, and cytology. $A D$ mark was suggestive of underlying $\beta$-amyloid $(A \beta)$ but not tau neuropathology $\left(\mathrm{A} \beta_{42} 252.1 \mathrm{pg} / \mathrm{mL}\right.$, total tau $143.6 \mathrm{pg} /$ $\mathrm{mL}$, phosphorylated tau $16.95 \mathrm{pg} / \mathrm{mL}, \mathrm{A} \beta_{42} /$ total tau index 0.62).

Cardiac MRI was without infiltrative disease. Left submandibular lymph node biopsy showed reactive follicular hyperplasia. A slit-lamp examination showed no evidence of ocular sarcoidosis.

Three weeks after admission, the patient had repeat lumbar puncture, with persistent pleocytosis (92 white blood cells/ $\mathrm{mm}^{3}$; $82 \%$ lymphocytes with $3 \%$ atypical/reactive) and elevated CSF total protein $(244.5 \mathrm{mg} / \mathrm{dL})$. Additional CSF studies were negative for Borrelia PCR, cytomegalovirus PCR, Epstein-Barr virus PCR, VZV PCR, VZV IgG, VZV IgM, fungal smear, and angiotensin-converting enzyme. However, repeat CSF Lyme IgG and IgM were positive. Given negative HSV on Biofire testing with equivocal IgM, acyclovir was discontinued. She completed a 28-day course of IV ceftriaxone.

Two months after her initial presentation in neuroimmunology clinic, the patient had continued bizarre affect, aprosodic speech, impaired reverse digit span, reduced verbal fluency, and poor abstraction. Her facial palsy resolved, but she displayed evidence of bilateral L5 radiculopathies and required a walker for ambulation.

In cognitive clinic nearly 3 months later, collateral history supported an underlying neurodegenerative disorder diagnosis. The patient's limited speech output, restricted affect, and increasingly ritualized behaviors had started years previously. Her job performance had suffered only in the previous year. Her falls started only with her acute decompensation. Her examination demonstrated evolving extrapyramidal dysfunction with reduced blink rate, hypophonia, symmetrical bradykinesia, and prominent postural instability on pull testing. She had reduced velocity of saccadic eye movements in all directions. Repeat dedicated CT-PET brain showed asymmetric bilateral frontal and anterior temporal hypometabolism.

\section{Discussion}

This is an interesting case of a middle-aged woman presenting with layers of acute, subacute, and chronic symptoms. The patient had years of disordered language with decreased speech output and behavioral abnormalities including repetitive and compulsive activities and restricted affect. This was followed by months of decline that was recognized as poor work performance and neglect of domestic chores. She acutely decompensated with bizarre behavior and falls. She presented with asymmetric parkinsonism, frontal release signs, and patchy hyperreflexia and developed a peripheral facial palsy within a week.

The patient's hyponatremia likely contributed to her worsening confusion, attention deficits, and unsteady gait with falls. ${ }^{1}$ Although she had multiple possible pharmacologic causes of SIADH, her neuroborreliosis may have contributed. $^{2}$ Her initial patchy hyperreflexia was difficult to localize due to conflicting processes including hyperthyroidism and Lyme radiculopathy. Her hyperreflexia resolved following resolution of her hyperthyroidism.

Given the patient's CSF pleocytosis, elevated CSF protein, and positive CSF Lyme antibodies, she fit the strictest neuroborreliosis diagnostic criteria. ${ }^{3}$ Her examination and imaging were consistent with Lyme radiculitis and cranial neuropathies that are common manifestations of neuroborreliosis. ${ }^{4}$ Lyme involvement of the parenchymal CNS is rare and tends to respond rapidly to antibiotics. ${ }^{3}$

Months after appropriate treatment of the patient's hyponatremia and neuroborreliosis, she continued to have cognitive and behavioral abnormalities consistent with a behavioral variant FTD (bvFTD) syndrome. ${ }^{5}$ She also displayed elements of a progressive supranuclear palsy (PSP) syndrome with extrapyramidal signs and ocular motor dysfunction. Clinical-neuropathologic correlation studies have contributed to an evolving understanding of PSP as a disease with multiple syndromic presentations, including the classic syndrome involving early supranuclear gaze palsy and postural instability (probable PSP with Richardson syndrome), PSP with progressive gait freezing within 3 years, PSP with predominant parkinsonism, and PSP with predominant frontal presentation (probable PSP-F). ${ }^{6,7}$ Probable PSP-F overlaps with bvFTD substantially, with common core features including apathy, executive dysfunction, disinhibition, and obsessive-compulsive or perseverative behaviors. In this case, atrophy of the midbrain including MRI showing a pons-to- 
midbrain diameter ratio of 0.50 supports a PSP spectrum condition. ${ }^{8}$ Syndromic variability in neurodegenerative diseases such as PSP highlights the importance of distinguishing between syndromic and neuropathologic diagnoses and the value of a 3-tiered neurocognitive formulation encompassing syndrome, severity, and expected neuropathology. ${ }^{9}$ Given the patient's ADmark CSF results, there may be additional underlying $A \beta$ plaque neuropathology. Familial autosomal dominant gene mutations causing PSP are rare. ${ }^{10}$ Genetic testing has not yet been performed.

This case provides insight into the layered presentation of multiple intersecting processes, including hyponatremia, hyperthyroidism, neuroborreliosis, and probable PSP-F. Given the patient's limited functional reserve from an underlying neurodegenerative process, her acute disorders were likely the tipping points leading to her presentation. This case is a reminder that the Occam razor cannot always explain complex clinical presentations.

\section{Study funding}

No targeted funding reported.

\section{Disclosure}

The authors report no disclosures relevant to the manuscript. Go to Neurology.org/N for full disclosures.

\section{Appendix Authors}

\begin{tabular}{|c|c|c|c|}
\hline Name & Location & Role & Contribution \\
\hline $\begin{array}{l}\text { Tara C. } \\
\text { Carlisle, } \\
\text { MD, PhD }\end{array}$ & $\begin{array}{l}\text { Brigham and Women's } \\
\text { Hospital, Department of } \\
\text { Neurology; Massachusetts } \\
\text { General Hospital, } \\
\text { Department of Neurology; } \\
\text { Harvard Medical School, } \\
\text { Boston }\end{array}$ & Author & $\begin{array}{l}\text { Drafted the } \\
\text { manuscript for } \\
\text { intellectual } \\
\text { content }\end{array}$ \\
\hline
\end{tabular}

\section{Appendix (continued)}

\begin{tabular}{|c|c|c|c|}
\hline Name & Location & Role & Contribution \\
\hline $\begin{array}{l}\text { Kristin M. } \\
\text { Galetta, } \\
\text { MD }\end{array}$ & $\begin{array}{l}\text { Brigham and Women's } \\
\text { Hospital, Department of } \\
\text { Neurology; Massachusetts } \\
\text { General Hospital, } \\
\text { Department of Neurology; } \\
\text { Harvard Medical School, } \\
\text { Boston }\end{array}$ & Author & $\begin{array}{l}\text { Revised the } \\
\text { manuscript for } \\
\text { intellectual } \\
\text { content }\end{array}$ \\
\hline $\begin{array}{l}\text { Scott M. } \\
\text { McGinnis, } \\
\text { MD }\end{array}$ & $\begin{array}{l}\text { Brigham and Women's } \\
\text { Hospital, Department of } \\
\text { Neurology; Massachusetts } \\
\text { General Hospital, } \\
\text { Department of Neurology; } \\
\text { Harvard Medical School, } \\
\text { Boston }\end{array}$ & Author & $\begin{array}{l}\text { Revised the } \\
\text { manuscript for } \\
\text { intellectual } \\
\text { content }\end{array}$ \\
\hline $\begin{array}{l}\text { Tamara } \\
\text { Bockow } \\
\text { Kaplan, } \\
\text { MD }\end{array}$ & $\begin{array}{l}\text { Brigham and Women's } \\
\text { Hospital, Department of } \\
\text { Neurology; Harvard Medical } \\
\text { School, Boston }\end{array}$ & Author & $\begin{array}{l}\text { Revised the } \\
\text { manuscript for } \\
\text { intellectual } \\
\text { content }\end{array}$ \\
\hline
\end{tabular}

\section{References}

1. Renneboog B, Musch W, Vandemergel X, Manto MU, Decaux G. Mild chronic hyponatremia is associated with falls, unsteadiness, and attention deficits. Am J Med 2006;119:71.e1-8.

2. Siddiqui N, St Peter DM, Marur S. Ticks and salt: an atypical case of neuroborreliosis. J Community Hosp Intern Med Perspect 2017;7:358-362.

3. Halperin JJ. Neuroborreliosis. J Neurol 2017;264:1292-1297.

4. Schwenkenbecher P, Pul R, Wurster U, et al. Common and uncommon neurological manifestations of neuroborreliosis leading to hospitalization. BMC Infect Dis 2017; 17:90.

5. Rascovsky K, Hodges JR, Knopman D, et al. Sensitivity of revised diagnostic criteria for the behavioural variant of frontotemporal dementia. Brain 2011;134:2456-2477.

6. Höglinger GU, Respondek G, Stamelou M, et al. Clinical diagnosis of progressive supranuclear palsy: the Movement Disorder Society criteria. Mov Disord 2017;32: 853-864.

7. Williams DR, Lees AJ. Progressive supranuclear palsy: clinicopathological concepts and diagnostic challenges. Lancet Neurol 2009;8:270-279.

8. Mangesius S, Hussl A, Krismer F, et al. MR planimetry in neurodegenerative parkinsonism yields high diagnostic accuracy for PSP. Parkinsonism Relat Disord 2018; 46:47-55.

9. Dickerson BC, McGinnis SM, Xia C, et al. Approach to atypical Alzheimer's disease and case studies of the major subtypes. CNS Spectr 2017;22:439-449.

10. Siuda J, Fujioka S, Wszolek ZK. Parkinsonian syndrome in familial frontotemporal dementia. Parkinsonism Relat Disord 2014;20:957-964. 


\section{Neurology}

\section{Clinical Reasoning: A 58-year-old woman presents with progressive memory deficits, odd behavior, and falls}

Tara C. Carlisle, Kristin M. Galetta, Scott M. McGinnis, et al.

Neurology 2020;94;e557-e561 Published Online before print January 20, 2020

DOI 10.1212/WNL.0000000000008896

This information is current as of January 20, 2020

\section{Updated Information \&} Services

References

Subspecialty Collections

\section{Permissions \& Licensing}

Reprints including high resolution figures, can be found at: http://n.neurology.org/content/94/5/e557.full

This article cites 10 articles, 0 of which you can access for free at: http://n.neurology.org/content/94/5/e557.full\#ref-list-1

This article, along with others on similar topics, appears in the following collection(s):

\section{Bacterial infections}

http://n.neurology.org/cgi/collection/bacterial_infections

Electrolyte

http://n.neurology.org/cgi/collection/electrolyte

Endocrine

http://n.neurology.org/cgi/collection/endocrine

Frontotemporal dementia

http://n.neurology.org/cgi/collection/frontotemporal_dementia

Progressive supranuclear palsy

http://n.neurology.org/cgi/collection/progressive_supranuclear_palsy

Information about reproducing this article in parts (figures,tables) or in its entirety can be found online at:

http://www.neurology.org/about/about_the_journal\#permissions

Information about ordering reprints can be found online:

http://n.neurology.org/subscribers/advertise

Neurology ${ }^{\circledR}$ is the official journal of the American Academy of Neurology. Published continuously since 1951, it is now a weekly with 48 issues per year. Copyright (C 2020 American Academy of Neurology. All rights reserved. Print ISSN: 0028-3878. Online ISSN: 1526-632X.

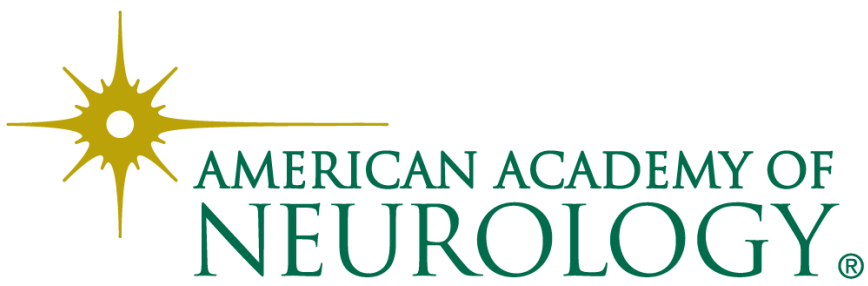

